\title{
A Informação na Ciência da Informação
}

The information in Information Science

\author{
Johanna W. Smit \\ Doutorado em análise do discurso pela Universidade de Paris-I. \\ Professora doutora do Departamento de Biblioteconomia e Documentação da ECA - USP \\ E-mail: johannawsmit@gmail.com
}

\section{Resumo}

Proposta de delimitação do conceito de informação no contexto da Ciência da Informação e de sua história. Os desafios representados para a Ciência da Informação quando a informação hoje não mais se encontra restrita às instituições tradicionalmente vocacionadas para sua preservação.

Palavras-chave: Informação. Ciência da Informação. Arquivos. Bibliotecas. Museus.

\begin{abstract}
Proposed delimitation of the concept of information in the context of Information Science and its history. The challenges faced by Information Science to make information available not only in institutions traditionally aimed at its preservation.
\end{abstract}

Keywords: Information. Information Science. Archives. Libraries. Museums.

A informação perpassa o cotidiano, a vida doméstica e profissional: os meios de comunicação transmitem informações, o guia turístico presta informações, o aluno absorve e o professor transmite, o médico necessita e o administrador decide em função da informação... ou das informações: singular ou plural. Tudo, literalmente tudo, pode ser portador de informação: a fumaça nos filmes de faroeste informa o perigo pressentido pelo índio, uma árvore informa sobre o ecossistema de um local, o prédio nos informa sobre a cidade, o arquiteto ou o modo de vida da população local, assim como a obra artística nos informa sobre as representações simbólicas dos povos e o sonho abre caminho para as informações do inconsciente - a onipresença da informação parece já não ser mais portadora de informação alguma: se há informação em toda parte, se tudo pode ser considerado informacional, então nada é. Há uma explosão ou um caos informacional, nele estamos (ou navegamos e surfamos, para atualizar a linguagem), mas para tentar uma reflexão mais aprofundada sobre o tema, torna-se indispensável propor um recorte no universo informacional para melhor delimitar o conceito de informação na Ciência da Informação. 


\section{A Informação Institucionalizada}

O sinal de fumaça mandado pelo índio para alertar sobre a aproximação de um perigo é passível de decodificação: em função dessa decodificação os outros índios tomam decisões, tais como fugir ou preparar uma armadilha. No entanto, este sinal de fumaça não poderá ser "lido" no futuro, ou utilizado para treinamento dos jovens índios pois o sinal se dissipará e não poderá ser recuperado ou reutilizado.

Um acidente geográfico (rio ou montanha, por exemplo) não se dissolve no ar com a mesma facilidade da nuvem de fumaça e pode "servir", por séculos, para informar sobre as condições geológicas, climatológicas, etc. do local. No entanto, não é obviamente possível transportar todos os alunos de $1^{\circ}$ grau de todas as escolas do mundo inteiro para a foz do rio Amazonas, objetivando informá-los sobre o que seja o fenômeno da pororoca. Com toda certeza o professor japonês, ao tratar da pororoca, utilizará um texto, imagens ou um vídeo. A "informação" transmitida pelo acidente geográfico tem que ser vista "in loco" ou deve ser substituída por uma representação (texto, imagem, som) para adquirir "portabilidade" e nesta condição poder ser acessada em outro local.

Do que precede deduz-se que a informação, para poder ser utilizada por mais pessoas sem limitações de tempo e espaço, supõe que a mesma tenha sido "documentada", ou seja, registrada. $\mathrm{O}$ registro torna a informação menos volátil e mais portátil. A informação não registrada em algum tipo de suporte, tecnologia ou código, por mais importante que seja, não é passível de uma socialização mais ampla, uma vez que seu acesso é condicionado pelas variáveis espaciais e temporais. Informação registrada equivale ao conceito de documento, embora o mesmo tenha sido investido de valores diferenciados ao longo do tempo ${ }^{1}$.

Temos assim uma primeira delimitação - importante - para a informação na Ciência da Informação: esta informação deve ser registrada.

Diante da fragilidade, ou precariedade, da informação não registrada a humanidade desde a antiguidade formalizou a necessidade de estocar a informação registrada e disponibilizá-la para que esta pudesse ser utilizada pelas mais variadas categorias sociais: cidadãos, sábios, estudantes, poderosos, cientistas, gerentes, etc. Neste movimento nasceram instituições bastante variadas tais como bibliotecas, museus, e arquivos e, mais tarde, os

\footnotetext{
${ }^{1} \mathrm{O}$ conceito de documento, central para a Ciência da Informação, não será aqui desenvolvido. Recomendo os estudos de Lund (2009) e Ortega e Lara (2010), que fornecem ótimas análises sobre o tema.
}

InCID: R. Ci. Inf. e Doc., Ribeirão Preto, v. 3, n. 2, p. 84-101, jul./dez. 2012. 
centros e sistemas de documentação ou informação. Mais tarde ainda, sintetizando traços desta variada gama de instituições, nasceram os centros de memória. Por fim, com a tecnologia e a internet, uma nova variedade de "instituições" passou a disponibilizar a informação para que ela possa ser acessada por uma miríade de pessoas: sites, blogs, repositórios, bancos de dados, etc. Quase ${ }^{2}$ todas estas instituições se caracterizam pela institucionalização da informação: esta é o principal produto de sua atividade. A informação disponibilizada por uma instituição passa a ser uma informação "que existe", ou seja, que é socialmente considerada existente, importante e potencialmente útil para alguém, ou alguma instituição, em algum momento, próximo ou distante. A informação institucionalizada carrega um "selo de qualidade", pois é fruto de opções e foi considerada digna de ser preservada.

Voltando à restrição apontada no parágrafo acima, quando afirmei que "quase" todas as instituições atribuem um selo de qualidade à informação, um dos embates que hoje presenciamos na Ciência da Informação se relaciona à credibilidade da informação veiculada por sites, blogs pessoais ou institucionais, repositórios ou bases de dados, que em alguns casos merecem o selo de qualidade e em outros casos não passam por nenhum crivo e não têm como ostentar o referido selo ${ }^{3}$.

A decisão segundo a qual certa informação, na medida em que considerada potencialmente útil, deva ser preservada, é determinada pelas condições culturais que prevalecem no momento da decisão. Ou seja: a decisão sobre o "poder informacional" de algum fato, evento ou registro é situacional. Buckland (1991) relata que na Idade Média era considerado importante conseguir distinguir as mulheres sérias das bruxas. Para tanto, convencionou-se submeter as mulheres sob suspeita a um teste que consistia em mergulhar totalmente a mulher num tanque cheio de água: se a mulher flutuasse, considerava-se que esta era a prova inequívoca de sua condição de bruxa (e a fogueira determinaria o último capítulo de sua vida), ao passo que a morte por afogamento provava a condição de mulher honesta. $\mathrm{Na}$ época, situacional e consensualmente o teste informava algo (e seguramente determinou o destino de certo número de mulheres): hoje o teste, caso aplicado, transmitiria com toda certeza outra informação.

\footnotetext{
${ }^{2}$ A restrição a algumas "instituições" será discutida logo a seguir.

${ }^{3}$ Não voltarei à questão neste texto, mas evidentemente o tema carece de muita pesquisa para elaborar critérios que permitam identificar a existência ou inexistência do referido "selo de qualidade" e alertar o público quanto à questão.
} 
Conclui-se que "ser informacional" é relativo e historicamente determinado: as instituições que estocam a informação determinam qual informação deve ser coletada em função de um consenso ${ }^{4}$ (que pode durar períodos variáveis de tempo) sobre a natureza informacional dos registros a serem estocados.

As instituições que têm por atribuição a estocagem de informações foram, através dos tempos, estocando uma informação registrada de acordo com o consenso de cada momento. Em outros termos, estas instituições estocam uma variedade de documentos/objetos aos quais se atribui uma probabilidade de utilidade no futuro (BUCKLAND, 1991) ou um poder de prova, na acepção arquivística (BELLOTTO, 2002).

Temos assim uma segunda delimitação - igualmente importante - para a informação na Ciência da Informação: essa informação é institucionalizada, o que lhe confere um "selo de qualidade”.

\section{Abordagens da Informação ao Longo do Tempo}

A informação, como acima delimitada no contexto da Ciência da Informação e, portanto, não mais aquela noção genérica de toda e qualquer informação, foi recebendo abordagens diferentes ao longo do tempo. A bibliografia se refere a estas abordagens com qualificações tais como "paradigmas" e "quebra de paradigmas". Não me parece que este seja o caso: com o tempo diferentes características da informação, que a acompanham desde o início, foram sendo enfatizadas, sem que ocorresse a substituição de uma característica por outra $^{5}$. Concordo, portanto, com Capurro (2003) e Vega-Almeida, Fernández-Molina e

\footnotetext{
${ }^{4}$ A título de exemplo, pode-se observar que a história dos museus é muito influenciada, até a década de 50 do século passado, pelas ideias de "poder" ou do "belo": musealizam-se objetos relacionados às pessoas ou situações historicamente importantes (caneta empregada na assinatura do tratado de paz, pente utilizado pela rainha, brinquedo que foi do príncipe, baixela de prata utilizada pelo senhor de engenho, etc.). Em seguida, influenciada por outras variáveis, a museologia considera informacionais os brinquedos utilizados pelas crianças da classe baixa, os vasos de flor feitos a partir de latas de óleo ou o martelo utilizado pelos operários de determinada fábrica. Assiste-se, através destes exemplos, a uma mudança de critérios para determinar o que é considerado "informacional". Uma outra questão, bem diferente, diz respeito à ênfase, percebida na literatura arquivística, quando esta assume que não há seleção e que todo documento produzido ou recebido por uma instituição deverá ser encaminhado ao arquivo. A assertiva procede para quase todos os casos, mas sempre há documentos que - produzidos ou recebidos - não acabam adquirindo estatuto arquivístico: refiro-me à mala direta recebida, a documentos menores, de controles internos, que normalmente nem são conhecidos da instituição ou ainda a minutas de documentos descartados mas que, caso preservados, permitiriam detectar opiniões divergentes no encaminhamento de determinado tema. A teoria arquivística dispõe, consequentemente, que todo documento produzido ou recebido carrega poder informacional.

${ }_{5}^{5}$ Retomo, neste tópico, discussão iniciada no XVI Congresso Brasileiro de Arquivologia em 2010 (SMIT, 2010).
} 
Linares (2009), quando eles traçam a evolução do campo da Ciência da Informação como uma sucessão de três momentos paradigmáticos:

- paradigma físico;

- paradigma cognitivo;

- paradigma social.

Os autores acima citados não postulam a ocorrência de rupturas totais entre um paradigma e o seguinte, ao evidenciarem os importantes contributos de cada momento no contexto histórico em que imperaram, mas discutem ao mesmo tempo a exaustão de cada paradigma à medida que o mundo foi se alterando, as necessidades informacionais se tornando mais específicas e complexas, agregando novas demandas às demandas existentes. Assim sendo, os autores não preconizam o abandono de um paradigma em função daquele que o sucede, mas a incorporação de novos conceitos e uma priorização diferente de conceitos, desenhando assim tanto epistemologias diferentes do campo informacional como práticas diferenciadas.

Resumo a seguir os principais traços dos três paradigmas acima referidos, mantendome fiel à argumentação dos autores, que objetivam descrever o nascimento e a evolução da Ciência da Informação, em relação - ou em oposição - à biblioteconomia.

Paradigma físico (1945 até meados da década de 70) - consensualmente o pós-guerra é considerado o marco inicial da Ciência da Informação, que se implementou em oposição à biblioteconomia, já que essa não conseguia prover acesso à informação, cada vez mais volumosa e diferenciada para usuários cada vez mais especialistas e exigentes. A ênfase recai sobre o objeto da atividade de produção, organização e busca de informação, ou seja, a informação. O conhecimento, de acordo com esse paradigma, é objetivo, especializado e independe do sujeito cognoscitivo. Engenheiros, matemáticos e físicos concebem um tratamento da informação mais detalhado, mais voltado às suas necessidades informacionais, mas concebem este tratamento num enfoque que poderia ser chamado "tecno-centrista" e pelo qual o processo de busca da informação é determinista, não dinâmico e tampouco interativo, não sofrendo intervenção de elementos psicológicos e físicos. A relevância da informação recuperada é objetiva, podendo ser medida. De acordo com o paradigma físico a informação é representada por unidades, com características de "objetos" (BUCKLAND, 1991) que podem ser armazenados em algum lugar e transmitidos por canais, sendo que tanto a transmissão 
quanto a recepção não sofrem influências contextuais. A capacidade de compreensão da informação transmitida não é discutida, somente se a mesma "chegou a bom porto".

Paradigma cognitivo (1980 até meados da década de 90) - a transformação que se opera mundialmente, de rejeição da modernidade e da sociedade industrial, levando ao esgotamento do modelo da racionalidade moderna, introduz o conceito de relatividade a partir da crítica da objetividade que se supunha ser o fundamento da ciência moderna. Esta alteração paradigmática é especialmente atestada pelas ciências humanas e sociais, opondo-se à lógica das ciências exatas e altera a relação sujeito-objeto - desconsiderada pelas ciências exatas, mas determinante nas ciências humanas e sociais. A noção de sujeito é resgatada, na condição de agente transformador da informação em conhecimento. Instaura-se uma epistemologia individualista, trazendo consigo a consciência que a realidade do mundo material sempre é uma construção mental. A produção do conhecimento depende da mente humana, conceitochave deste momento. Pode-se considerar este momento "centrado-no-usuário", mas sempre um usuário individual, isolado, não inserido numa dimensão coletiva. O leitmotiv deste paradigma é o sujeito produtor de conhecimento, visando seu bem-estar e o desenvolvimento da humanidade, tornado possível pelo desenvolvimento dos indivíduos. O paradigma cognitivo opõe-se, efetivamente, ao paradigma físico, mas continua pressupondo a existência de estoques informacionais. Trata-se, em suma, de "iluminar" a outra ponta do contínuo informação produzida $\rightarrow$ informação estocada e organizada $\rightarrow$ informação recuperada e utilizada. Se o paradigma cognitivo trouxe novamente o usuário ao centro das atenções, do qual ele estava em grande parte alijado no paradigma físico, o momento seguinte resgata a historicidade deste usuário.

Paradigma social (199? em diante) - a cultura individualista gerou seu antídoto - os movimentos sociais e a busca por um projeto humanista alternativo. $\mathrm{O}$ ser humano como sujeito histórico relaciona-se tanto com a natureza como com a sociedade. A excessiva valorização da subjetividade aponta para a necessidade de um conhecimento interpretativo (e não mais descritivo), sustentado pela tríade sujeito-objeto-contexto. $\mathrm{O}$ usuário, de acordo com os pressupostos do paradigma, relaciona-se com a informação de forma sempre contextualizada, já que o mesmo procura e entende a informação em função tanto de suas redes semânticas individuais, mas também do contexto no qual vive, dos valores que o movem e de acordo com a necessidade informacional determinada pelo mesmo contexto. Torna-se evidente que o sujeito procura por informações, elaborando perguntas de acordo com aquilo que tanto o contexto social quanto seus conhecimentos individuais permitem, 
determinando um escopo dentro do qual a resposta será considerada útil, ou válida (SANTOS, 1987). O modo de formular a pergunta determina a resposta, inserindo tanto a busca de informação quanto sua apropriação e uso na relatividade contextual da qual decorrem. A Ciência da Informação, neste momento, se concebe, de fato, como uma ciência social, muito influenciada pelas tecnologias da informação e da comunicação (as TICs) e inserida nos propósitos da sociedade da informação. Obviamente, essa visão epistêmica do uso social da informação abre espaço para novas discussões acerca do papel e do poder da informação e dos sistemas de informação que, ao organizarem a informação, impõem aos usuários determinada visão de mundo. A compreensão dos contextos de produção e uso da informação (contextos social, organizacional ou profissional) constitui uma condição necessária para o trabalho com a informação.

O paradigma físico priorizou o objeto, o paradigma cognitivo enfatizou o sujeito, e o paradigma social enxerga o sujeito, contextualizado, em sua relação com o objeto-informação. Boaventura de Souza Santos descreve bem o surgimento de um paradigma emergente que não pode ser somente um paradigma científico, mas deve ser também um paradigma social (SANTOS, 1987).

Em suma, a informação, de acordo com o paradigma social, é entendida numa perspectiva ampla que envolve, além das mensagens presentes nos documentos (paradigma físico), processadas cognitivamente (paradigma cognitivo), o conhecimento dos contextos, motivações e intencionalidades dentro dos quais foram produzidas e podem ser buscadas e interpretadas (SARACEVIC, 1999).

\section{A informação nas instituições coletoras de cultura}

A expressão "instituições coletoras de cultura" cunhada por Homulos (1990) congrega instituições que reúnem uma informação considerada útil. Hoje a expressão poderia ser atualizada para "instituições disponibilizadoras de cultura", de forma a incorporar os novos sistemas de informação que não forçosamente coletam (e, portanto, não têm acervo) mas que organizam e disponibilizam informações de toda natureza.

Como acima dito, a informação é institucionalizada porque a ela foi atribuída uma potencialidade de utilidade informacional. Uma importante bibliografia discorre sobre esta "utilidade informacional", associando-a a uma redução - ou aumento - da incerteza ou 
ignorância sobre certo fato. A visão tradicional da informação, por um lado, caracteriza-a por seu caráter quantificável, e por outro lado associa-a de forma excessivamente mecânica ao conceito de comunicação. Como veremos adiante, informar e comunicar não se confundem, por mais que designem operações muitas vezes complementares.

De toda maneira desta visão inicial da informação, muito marcada pela engenharia dos sistemas de telecomunicações, e descartando por ora a questão comunicacional, pode-se isolar uma entidade - a informação - "qualificada como um instrumento modificador da consciência do homem e de seu grupo" (BARRETO, 1994, p.3).

A informação presente nas instituições coletoras de cultura varia de acordo com os objetivos das respectivas instituições. Não parece mais pertinente fundamentar a distinção entre instituições em função do tipo de documentos por elas mantido. Esta distinção, hoje totalmente ultrapassada, encontra suas raízes na reificação do conceito de "documento", em detrimento da informação nele contida ou, melhor ainda, da função por esta exercida nos diferentes ambientes. Assim sendo, torna-se inoperante distinguir as instituições pelo tipo de documento que nelas predomina, por mais que esta predominância, em boa parte, continue sendo observada na prática e reiterada pelo senso comum. Em outros termos, por mais que as bibliotecas continuem, predominantemente, estocando livros e periódicos, ao passo que os arquivos acumulam documentos administrativos e os museus objetos, esta distinção não se sustenta, uma vez que a função atribuída a estes documentos determina uma diferenciação mais fundamentada ${ }^{6}$. O aprofundamento da reflexão sobre a função (ou o uso) das informações estocadas abre um campo fértil para pesquisas e debates, insuficientemente explorado, a meu ver.

Homulos (1990) sinaliza pistas norteadoras para o debate ao recusar o estabelecimento de fronteiras rígidas entre museus, arquivos e bibliotecas e propor sua disposição ao longo de um grande contínuo tendo as bibliotecas numa extremidade, os museus na outra e os arquivos no meio do contínuo. $\mathrm{Na}$ acepção do autor cada instituição, de acordo com o momento e as necessidades específicas para alguns conjuntos documentais se colocaria "um pouco mais" em certa posição (a biblioteca adotando procedimentos arquivísticos, por exemplo), sendo que a localização da instituição no contínuo varia de acordo com a atividade específica enfocada. $\mathrm{O}$

\footnotetext{
${ }^{6}$ A título de exemplo cito a irrupção do documento eletrônico nas diferentes ambiências, apontando para a fragilidade da distinção das instituições pelo tipo de documento estocado, uma vez que o documento eletrônico está presente em todas as instituições, mas cumprindo funções diferentes. $\mathrm{O}$ documento audiovisual fornece outro exemplo para a mesma discussão (SMIT, 1993).
} 
autor menciona, dentre outros, um critério que - hoje - melhor distingue as instituições, ou seja, o "conteúdo informacional" de cada uma: se na biblioteca a coleção dos documentos representa a própria informação estocada, no museu os objetos pouco informam sobre si mesmos mais informam potencialmente muito sobre a sociedade que os gerou ou utilizou, ao passo que no arquivo os documentos informam sobre a instituição que os acumulou.

De toda forma, por mais que as instituições tenham suas especificidades em termos de objetivos e critérios de formação do estoque informacional, nelas predomina um objetivo comum: todas se preocupam com a organização da informação objetivando sua disponibilização.

Tempos atrás batizei a irmandade entre as três principais instituições coletoras de cultura (biblioteca, arquivo e museu) com a expressão “3 Marias” (SMIT, 1993), com a finalidade de chamar a atenção tanto para a irmandade que as une como também para os mútuos desconhecimentos. As três irmãs ignoram-se em boa parte, o que contribui para sua falta de visibilidade social e retarda ou impede operações colaborativas. Os documentos audiovisuais e depois os eletrônicos apontam claramente para os problemas acarretados pela mútua ignorância, uma vez que presentes em todos e desafiando a todos diante de novas questões. As novas configurações informacionais (sites, blogs, repertórios, bases de dados), quando ornadas com o "selo de qualidade" atualizam a mesma questão pois geralmente amalgamam escrita, iconografia, som, gráficos, filmes e não se enquadram na clássica distinção entre as três irmãs.

Uma visão funcionalista (qual é a função atribuída ao documento neste contexto: ele informa? ele informa sobre? ele prova? ele remete a qual outra informação com qual função? etc.) parece hoje mais fértil, pois critérios de organização e representação da informação certamente deverão levar em conta a função atribuída aos documentos por determinado serviço ou sistema de informação.

Neste texto não se pretende analisar detalhadamente as causas e consequências da irmandade complicada entre arquivos, museus e bibliotecas, mas sugere-se que a questão integre agendas de pesquisa variadas quando o objetivo maior é enunciado em termos tais como tornar a informação acessível para aqueles que dela necessitam ou que a desejam. 


\section{Informação e Conhecimento}

A informação que permite modificar o estado de conhecimento de um indivíduo ou grupo sobre certo fato não pode ser assimilada ao conhecimento. No mesmo sentido, é igualmente inoperante identificar a informação com a comunicação, outro conceito que frequentemente se encontra associado ao primeiro de forma equivocada. Voltarei logo em seguida à distinção entre informação e comunicação, após expor a distinção entre informação e conhecimento.

O conhecimento é elaborado por cada indivíduo a partir de apropriações de informações disponibilizadas de diversas maneiras, inclusive através das instituições coletoras de cultura. Em outros termos, a informação, por si só, não concede o conhecimento (SFEZ, 1996, p.5 $)^{7}$. Ainda na ótica deste autor, a informação, ao chegar ao usuário, supõe, para poder ser processada e transformada em conhecimento, a existência de duas competências: uma competência linguística (que lhe permite entender os termos da linguagem utilizada) e uma competência enciclopédica, que lhe permite entender do que se fala. "É nesta condição que ele pode compreender e interpretar a mensagem" (SFEZ, 1996, p.6). Obviamente, as duas competências citadas pelo autor pressupõem que a pessoa esteja disponível para receber a informação. Assim sendo, para que uma informação possa ser processada pelo indivíduo este deve encontrar, em sua rede cognitiva, algum ponto ao qual a informação nova possa ser conectada (a competência enciclopédica) de forma a conseguir situar a informação nova num conjunto maior (a rede cognitiva). Conclui-se do que precede que a apropriação da informação pelo indivíduo, visando a geração de conhecimento novo, supõe a existência de um conhecimento anterior (a rede cognitiva) bem como a disposição de alterar, completar ou rever este conhecimento.

Deve-se, pois, distinguir a informação do conhecimento. A informação, identificada enquanto estruturas significantes disponibilizadas por um amplo leque de instituições culturais, implica passividade: a informação, enquanto objeto disponibilizado, nada faz, não aciona ou acarreta nada - o homem faz algo com ela (ou seja, gera o conhecimento). O conhecimento, por sua vez, é gerado a partir de informações estruturadas e interconectadas de forma totalmente subjetiva por cada indivíduo. O conhecimento é forçosamente individual e subjetivo, produto da apropriação, pelo indivíduo, de informações e da estruturação

\footnotetext{
${ }^{7}$ Lucien Sfez emprega a palavra "saber" na tradição francesa para denominar o conhecimento, no sentido empregado neste texto.
} 
particular dada a estas. “(...) A produção dos estoques de informação não possui um compromisso direto e final com a produção do conhecimento" (BARRETO, 1994, p. 4).

\section{Informação e Comunicação}

Retomando as diferentes abordagens que nortearam a leitura da função da informação na sociedade e em relação aos indivíduos, o modelo matemático de comunicação de Shannon e Weaver, datado da década de 50 do século passado, e determinado pelo enorme investimento (financeiro e intelectual) que se fazia na época nas redes de telecomunicações, é tradicionalmente resumido pela existência de uma fonte e um receptor, sendo que a mensagem transita por um canal que leva da fonte ao receptor. A informação foi inicialmente muito analisada na condição de produto gerado pela fonte, enfatizando o polo inicial do processo comunicacional. A observação do gerador (fonte) exclui o receptor: ou este "está excluído do processo, ou não é necessário para a sua explicação" (BARRETO, 1994, p.3) ${ }^{8}$. A ênfase deslocou-se, a partir dos anos 70 do século passado, para o receptor reforçando desta feita a "intenção semântica da transferência, adjetivando o conceito com o significado da mensagem, seu uso efetivo e a ação resultante do uso" (BARRETO, 1994, p.3). A comunicação passa a se preocupar com a recepção, inaugurando novas discussões, deixando de lado uma visão "mecânica" da transferência de informação, que deixa de ser medida em termos de bits e bytes e passa a ser determinada por mecanismos semânticos, ou cognitivos, de recepção da informação. Para que a informação possa ser apropriada, ela deve ser entendida, tanto no sentido linguístico quando enciclopédico. Nesta ótica, não basta enviar informações para comunicar: a comunicação só se efetiva quando o receptor a "recebe", no sentido pleno do termo, ou seja, quando este tem condições para se apropriar desta informação, interiorizá-la, introduzi-la em seu estoque de conhecimentos.

Assim como a informação, a comunicação tampouco constrói o conhecimento, e ambas estão submetidas a um conhecimento preliminar do receptor.

\footnotetext{
${ }^{8}$ A bem da verdade, as diferentes teorias matemáticas da informação, hoje identificadas como modelos de comunicação, nunca foram apresentadas enquanto teorias de comunicação. Lasswell, por exemplo, que se baseou nos trabalhos de Shannon e Weaver, refutou reiteradas vezes a utilização que se vinha fazendo de suas ideias, o que não impediu muitos sociólogos e estudiosos dos meios de comunicação de massa a adotá-las. Hoje, no entanto, não se admite mais a utilização, sem restrições, do modelo matemático de comunicação posto que o receptor não é mais visto como um sujeito passivo no processo, mas como alguém que "retroalimenta" o sistema, alternando as funções de emissor e receptor. Os críticos mais ferrenhos à teoria da comunicação tradicional chegam a discutir sua visão a-histórica do processo comunicacional. Recomendo o artigo de Dervin e Nilan (1986) para uma transposição da mesma discussão para o tema aqui tratado.
} 
Resumindo, as atuais abordagens da informação e da comunicação privilegiam o usuário: em função de suas competências e disposições específicas o processo de comunicação pode ser efetivamente realizado, transferindo neste caso informações que, ao serem incorporadas à rede cognitiva, podem gerar conhecimento novo, forçosamente individual. Este conhecimento, se registrado, adquire um novo estatuto de informação que poderá ser socializado e potencialmente incorporado por algum indivíduo para gerar novo conhecimento.

\section{Informação para Todos}

Em função das acepções aqui dadas à informação, ao conhecimento e à comunicação, torna-se claro que "a ideia de que a informação poderia ser igualitariamente distribuída por uma comunicação que apenas transmitisse, pareceria não só um erro, disfarçado em utopia, mas um perigo real" (SFEZ, 1996, p.6). Dito em outros termos, a simples disponibilização da informação não garante sua comunicação ou sua contribuição no processo de geração do conhecimento. Obviamente, se a informação não for disponibilizada, nenhum processo de geração do conhecimento novo pode ser instaurado, mas sua simples disponibilização, como já reiterado, tampouco garante a elaboração do conhecimento.

O sonho otletiano da farta distribuição de informações como condição necessária e suficiente para a melhoria da sociedade e da qualidade de vida do cidadão torna-se irreal, utópico, impossível. Nesta perspectiva, os projetos envolvendo bibliotecas, arquivos e museus abertos ao cidadão, adquirem uma importância diferenciada, na medida em que obviamente necessários, enquanto disponibilizadores de informação institucionalizada, mas ao mesmo tempo insuficientes para a melhoria das condições de vida do cidadão, uma vez que estas são determinadas por uma capacidade apropriativa da informação, capacidade esta elaborada e fomentada, oficialmente, pelo processo educacional do indivíduo, e não pelas instituições coletoras de cultura. Retomando um antigo provérbio, pode-se afirmar que as instituições coletoras de cultura fornecem o peixe, mas não têm por missão ensinar a pescar. 


\section{O Consumidor? da Informação}

Finalmente, em supondo o usuário com uma necessidade ou desejo de informação e em condições de detectá-la apesar da diversidade de instituições e suportes/códigos, cabe ainda analisar a informação disponibilizada pelas instituições afim de nela detectar variáveis que possam comprometer, ou subsidiar, o processo de busca de informação tendo em vista a geração de um conhecimento.

Em primeiro lugar, deve-se ter claro que as instituições disponibilizam, no mínimo, dois tipos diferentes de informação: a informação contida nos documentos e elaborada por outros (autor, pintor, jornalista, administrador, escritor, etc.) ao lado da informação gerada pela própria instituição coletora de cultura.

A instituição, ao "reunir, selecionar, codificar, reduzir, classificar e armazenar a informação" (BARRETO, 1994, p.4), toma determinadas decisões, aplica políticas, equaciona custos e respectivos benefícios, ou seja organiza e controla o estoque de informações. Para que a instituição possa disponibilizar a informação gerada por outros, ela elabora e disponibiliza uma informação documentária, secundária em relação à informação contida nos documentos. A ficha do catálogo da biblioteca, o guia do arquivo ou a explicação que acompanha um objeto no museu, limitando-nos a alguns exemplos muito tradicionais, constituem, de fato, uma informação secundária, de autoria da instituição coletora de cultura e de responsabilidade desta (DESANTES GUANTER, 1987).

Esta fabricação da informação documentária, de responsabilidade da instituição, não é neutra, como já vimos, e determina o acesso à informação estocada, tornando-se assim um filtro, ou mediador, na busca da informação. Cabe, portanto, além da constatação de que políticas institucionais obviamente influem no processo, uma última digressão sobre a fabricação da informação documentária.

A informação documentária elaborada pela própria instituição ou por um pool de instituições (no caso da alimentação cooperativa de bases de dados, por exemplo) pode ser resumida pelos seguintes termos: descrição dos documentos que registram a informação e descrição da informação contida nos documentos.

\footnotetext{
${ }^{9}$ A qualificação do usuário pelo termo "consumidor" é discutível mas aqui empregada para enfatizar seu direito à informação numa abordagem na qual ele exerce efetivamente seu direito de forma ativa.
} 
De acordo com cada instituição e os objetivos por ela perseguidos, é possível prever distribuições diferenciadas entre a descrição dos documentos ou da informação neles contida, mas via de regra as duas atividades são executadas, pois complementares. No entanto, estas descrições, que têm por objetivo propor uma representação dos documentos e das informações neles contidas adotam regras, códigos e procedimentos próprios. A opção por uma regra ou outra, um procedimento ou outro, um termo ou outro, considerada de responsabilidade e da "alçada" da instituição condiciona, no entanto, o teor da informação elaborada e, consequentemente, a facilidade ou dificuldade que o usuário terá para encontrar a informação desejada. Uma ampla bibliografia foi elaborada para avaliar as variáveis que impactam na busca pela informação: nesta eu ressaltaria a questão da escolha de termos para representar assuntos controversos ou sensíveis ${ }^{10}$.

Para além da avaliação das opções adotadas institucionalmente, outra discussão se apresenta, muito menos frequente na bibliografia. Voltemos à diferenciação entre informação e conhecimento. Para que a informação possa ser apropriada pelo indivíduo o mesmo tem que ter condições (ou seja, conhecimentos anteriores) para poder avaliar a informação que acaba de receber e situá-la num contexto maior. Transpondo esta discussão para o universo das instituições coletoras de cultura, a pergunta pode ser formulada como segue: o usuário tem condições de contextualizar a informação documentária (elaborada pela instituição) que serve de mediadora entre ele e o estoque informacional? Em outros termos, para que a função da mediação possa ser assegurada, o usuário deve ter condições para contextualizar a informação documentária, decodificá-la, ou seja, o usuário deve possuir conhecimentos que lhe permitam entender a informação que lhe é fornecida pela instituição a qual, por sua vez, estabelece o acesso ao estoque informacional. Retomando a argumentação inicialmente desenvolvida, o usuário deve possuir competências linguísticas e enciclopédicas para conseguir entender a informação documentária e, nestas condições, se apropriar verdadeiramente da mesma para seus fins específicos.

Neste ponto, duas atitudes por parte das instituições coletoras de cultura são possíveis:

- Ou bem elas centram sua análise no sistema informacional por elas criado e tendem a “educar" ou "treinar" o usuário para que este comece a entender como a informação foi tratada, em função de quais princípios, regras e procedimentos, esperando com isso instrumentalizá-lo;

\footnotetext{
${ }^{10}$ A título de exemplo cito as pesquisas de Hope Olson (2002) sobre termos utilizados para representar conceitos relacionados a questões de gênero ou de costumes.
} 
- Ou bem a instituição analisa a questão a partir do ponto de vista do usuário e tenta adequar a informação documentária a este (MORRIS, 1994).

Duas respostas, em suma, em sentidos contrários, e não forçosamente autoexcludentes. A partir da década de 90 do século passado as necessidades informacionais do usuário passaram a receber maior ênfase. A incorporação de folksonomias aos sistemas de informação e a possibilidade do usuário "tagear" a informação de acordo com seu ponto de vista representam avanços neste sentido, mas não mudam o essencial: a informação é selecionada, representada e organizada de acordo com princípios institucionais e estes princípios não são sempre suficientemente tornados públicos. É necessário, consequentemente, informar o usuário sobre os critérios adotados para selecionar documentos ou informações, além de informá-lo sobre o tratamento que é dado a estes documentos para representá-los, as políticas adotadas, as opções exercidas; deve-se fornecer o mapa da mina ao usuário.

A disponibilização da informação sobre as opções institucionais para tratamento da informação retira o usuário do papel passivo de quem simplesmente "recebe" uma informação, transformando-o num agente ativo, um cidadão-consumidor. O usuário da instituição coletora de cultura passa a ser um parceiro desta: um parceiro que é usuário mas que, para ser usuário em condições de se apropriar e avaliar a informação recebida, precisa saber como a informação documentária foi produzida. Deve-se, consequentemente, abandonar ideias filantrópicas e segundo as quais o usuário teria um direito meio difuso mas liberalmente aceito de ser informado sobre os critérios que presidiram a elaboração da informação documentária. Como relembra Desantes Guanter (1987), se há um direito de ser informado alguém deve ter sido investido do dever de informar. Quando o usuário consegue efetivamente entender a informação documentária que lhe está sendo transmitida, estabelece uma efetiva comunicação com o estoque informacional e, em última análise, pode avaliar a informação disponibilizada para selecionar o que melhor atender a seus anseios, necessidades ou desejos.

Preconiza-se, portanto, a necessidade do estabelecimento de um Código de Defesa do Consumidor da Informação: em sua ausência o usuário, relegado a um papel passivo, torna-se refém, ou presa fácil, da instituição e suas políticas. 


\section{Algumas conclusões, Certamente Provisórias}

O panorama mudou drasticamente nos últimos anos, a informação não está mais restrita às instituições coletoras de cultura e a "geração Google" (BRITISH LIBRARY, 2008) inicia qualquer busca de informação na internet e muitas vezes não lhe ocorre que a informação demandada possa ter sido institucionalizada em algum lugar (com o respectivo selo de qualidade). É hora de lembrar algumas verdades:

- A informação, para poder ser acessada, deve estar estocada e preservada em algum lugar - físico ou digital: "instituições" sempre existirão e serão imprescindíveis para a preservação da informação;

- A informação para ser encontrada deve ter sido de alguma forma organizada, representada, "tageada", etc.;

- O que mudou é que muita informação hoje é disponibilizada sem portar um "selo de qualidade";

- Sensibilizar os usuários para a relevância do conceito de qualidade (credibilidade, fidelidade, autenticidade) da informação reforça o principal objetivo da Ciência da Informação, a saber, contribuir para a melhoria das condições de vida do homem e da sociedade através do acesso à informação. Não há razão, portanto, para concluir que as instituições perderam terreno, mas torna-se imperioso incorporar efetivamente o usuário no fluxo informacional, de modo a alimentar um canal de comunicação em mão dupla entre instituições, respectivos acervos e usuários.

Como se pode observar, entre o discurso - populista - da disponibilização massiva de informações e a efetiva disponibilização de uma informação que possa ser utilizada de forma enriquecedora pela humanidade, há uma enorme distância. A simples disponibilização da informação não equivale ao exercício do dever de informar, pois o dever de informar remete ao dever de criar condições adequadas para a construção do conhecimento. Em outras palavras, a disponibilização da informação é necessária mas não suficiente para o exercício da cidadania.

A informação, no contexto da Ciência da Informação, é registrada e institucionalizada. Para poder cumprir sua missão as configurações informacionais devem, além de selecionar, organizar e disponibilizar a informação - atribuindo-lhe um selo de qualidade - fornecer 
explicações acerca dos procedimentos adotados de modo que o usuário possa exercer um papel ativo com condições para avaliar o selo de qualidade da informação à qual teve acesso.

\section{Referências}

BARRETO, A. A. A questão da informação. São Paulo em Perspectiva, São Paulo, v. 8, n. 4, p. 3-8, 1994.

BELlotTO, H. L. Arquivística: objetos, princípios e rumos. São Paulo: Associação de Arquivistas de São Paulo, 2002. (Scripta, 1).

BRITISH LIBRARY, JISC. Comportamiento informacional del investigador del futuro: informe CIBER. Anales de Documentación, v. 11, p.235-258, 2008. Disponível em: http://revistas.um.es/analesdoc/issue/view/2651. Acesso em: 12 mar. 2012.

BUCKLAND, M. Information as thing. Journal of the American Society for Information Science, v. 42, n. 5, p. 351-360, 1991.

CAPURRO, R. Epistemologia e ciência da informação. In: ENCONTRO NACIONAL DE PESQUISA EM CIÊNCIA DA INFORMAÇÃO, 5., Belo Horizonte, 2003. Disponível em: www.capurro.de/enancib_p.htm. Acesso em: 5 jul. 2010.

DERVIN, B., NILAN, M. Information needs and uses. Annual Review of Information Science and Technology, v. 21, p. 3-33, 1986.

DESANTES GUANTER, J. M. Teoria y régimen jurídico de la documentación. Madrid: Eudema, 1987. (Eudema Universidad: Manuales).

HOMULOS, P. Museums to libraries: a family of colleting institutions. Art Libraries Journal, v.15, n.1, p.11-13, 1990.

LUND, N. W. Document theory. Annual Review of Information Science and Technology, v. 43, p.399-432, 2009.

MORRIS, R. C. T. Toward a user-centered information service. Journal of the American Society for Information Science, v.45, n.1, p.220-230, 1994.

OLSON, H. A. The power to name: locating the limits of subject representation in libraries. Dordrecht: Kluwer Academic Publishers, 2002.

ORTEGA, C. D., LARA, M. L. G. A noção de documento: de Otlet aos dias de hoje. DataGramaZero, Rio de Janeiro, v. 11, n. 2, 2010. Disponível em: <http://www.dgz.org.br/abr10/F_I_art.htm>. Acesso em: 13 ago. 2012.

SANTOS, B. S. Um discurso sobre as ciências. Porto: Afrontamento, 1987.

SARACEVIC, T. Information science. Journal of the American Society for Information Science and Technology, v. 50, n.12, p.1051-1063, 1999. 
SFEZ, L. Informação, saber e comunicação. Informare, Rio de Janeiro, v. 2, n. 1, p.5-13, 1996.

SMIT, J. W. O documento audiovisual ou a proximidade entre as 3 Marias. Revista Brasileira de Biblioteconomia e Documentação, São Paulo, v. 26, n. 1/2, p. 81-85, 1993.

SMIT, J. W. A organização dos documentos no arquivo: do paradigma físico ao paradigma intelectual. In: CONGRESSO BRASILEIRO DE ARQUIVOLOGIA, XVI, 2010, Santos. Anais. Rio de Janeiro: Associação dos Arquivistas Brasileiros, 2010. CD-ROM.

VEGA-ALMEIDA, R. L., FERNÁNDEZ-MOLINA, J. C., LINARES, R. Coordenadas paradigmáticas, históricas y epistemológicas de La Ciencia de la Información: una sistematización. Information Research, v. 14, n. 2, paper 399, 2009. Disponível em: http://InformationR.net/ir/14-2/paper399.html. Acesso em: 05 jul. 2010. 